\title{
Papers published by Gustav Nylin
}

1. Two cases of dystrophia myotonica, type "Batten-Steinert-Curschman", with a graphic investigation of their states of contraction and the influence of tem perature thereon.

Uppsala Läkarförenings Förhandlingar 3-6, 329, 1926.

2. Studier over det s. k. underviktiga skolbarnet. Hygiea, Stockh. 91, 33, 1929.

3. a) Till·växt och standardomsättning hos folkskolebarn under olika perioder av året.

Nord. med. Tidskr. 1, 602, 1929.

3. b) Growth and standard metabolism in children of elementary schools during different periods of the year.

Verhandlungen des Vierzehnten Nordischen Kongresses für Innere Medizin.

Helsingfors 1930, 356.

4. Periodical variations in growth, standard metabolism and oxygen capacity of the blood in children.

Acta med. scand. 1929, Suppl. XXXI.

Papers published by Gustav Nylin

211

5. Skolans uppgift som fostrare av ett sunt släkte.

Stockholm 1931.

6. Nutidens uppfattning av Malling-Hansens undersökningar.

Föredrag å Kungl. Dövstumsinstitutet i Köpenhamn 11 okt. 1930.

7 Versuche über Funktionsprüfungen des Herzens (vorläufiger Bericht).

Z. klin. Med. 5i6, 284, 1931.

8 . a) Försök till funktionell hjärtdiagnostik.

Nord. med. Tidskr. 3, 769, 1931.

8 . b) Attempt at functional cardiac diagnosis.

Acta med. scand. 1932, Suppl. L, 54.

9. On the relation between the increase in height and the increase in weight in school children.

Acta paediat., Stockh. 11, 106, 1930.

10. Om sambandet mellan längdökning och viktökning hos skolbarn.

Nord. med. Tidskr. 2, 625, 1930.

11. Clinical tests of the function of the heart.

Acta med. scand. 1933, Suppl. LII.

12. Förhållandet mellan hjärtvolym och slagvolym som matt på hjärtfunktion.

Svenska Läkartidn. 10, 1, 1933.

13. The cardiac output of children.

Skand. Arch. Physiol. 66, 97, 1933. 
14. Untersuchungen über das Minutenvolumen des Herzens in 2 Fallen mit einseitigem künstlichem Pneumothorax.

Beitr. Klin. Tuberk. 83, 470, 1933.

15. The relation between heart volume and stroke volume in recumbent and erect positions.

Skand. Arch. Physiol. 69, 237, 1934.

16. Together with E. Lysholm and K. Quarnå. The relation between the heart volume and stroke volume under physiological conditions.

Acta radiol., Stockh. 15, 237, 1934.

17. Carl-August Ljunggren. Minnesord i Svenska Läkaresällskapet den 27 nov. 1934.

Hygiea, Stockh. 96, 785, 1934.

18. De kliniskt användbara hjärtfunktionsproven och deras betydelse. (Autoreferat.)

Svenska Läkaresällskapets Förhandlingar 1935, 449.

19. Together with H. C. lacobaeus and B. Almberg. Recherches sur Гinfluence d'une diminution expérimentale de la mobilité du thorax sur la dette d'oxygène

après travail gradué.

Acta med. scand. 86, 455, 1935.

20. The physiology of the circulation during puberty.

Acta med. scand. 1935, Suppl. LXIX.

21. De kliniskt användbara hjärtfunktionsproven och deras betydelse. Inledningsföredrag vid Nordiska kongressen for invärtes medicin i Köpenhamn 1935.

Nord. med. Tidskr. 10, 1737, 1935.

22. Functional heart tests and their clinical significance.

Acta med. scand. 1936, Suppl. LXXVIII, 64.

212

Papers published by Gustav Nylin

23. Standardomsättningens förhållande vid med stora digitondoser behandlade

fall av hjärtinsufficiens.

Nord. med. Tidskr. 12, 1829, 1936.

24. Några intryck från medicinska kliniker i Amerika våren 1937.

Medicinska Fòreningens Tidskr. 10, 245, 1937.

25. Die klinisch brauchbaren Herzfunktionsprüfungen und ihre klinische Bedeutung.

Zbl. inn. Med. 26, 529, 1937.

26. More recent developments of heart function tests.

J. Amer. med. Ass. 109, 1333, 1937.

27. Vitamin-B1-brist som orsak till hjärtinsufficiens.

Nord. med. Tidskr. 15, 1, 1938.

28. a) Digitalis inverkan på den s. k. relativa syreskylden i fall av latent hjärtinsufficiens med normal hjärtrytm. Nord. med. Tidskr. 15, 566, 1938.

28. b) L'influence de la digitale sur la dette relative d'oxygène dans Tinsuffisance cardiaque latente a rythme cardiaque normal. Arch. Mai. Cæur 66, 1010, 1939.

29. Together with G. Lüjestrand and E. Lysholm. The immediate effects of mus cular work on the stroke and heart volume in man. 
Skand. Arch. Physiol. 80, 265, 1938.

30. Together with T. Sällström. Three synchronized leads between fixed points on the heart projection on the chest wall.

Acta med. Scand. 96, 1, 1938.

31. The practical applicability of the cardio-pulmonary function test.

Acta med. Scand. 1938, Suppl. ХCП.

32. Together with G. Lüjestrand, E. Lysholm and C. G. Zachrisson. The normal heart volume in man.

Amer. Heart J. 17, 406, 1939.

33. Yrkessjukdomarna och samhällets åtgärder mot dem.

Diskussionsinlägg vid 22: a Almänna Svenska Läkarmötet 1939.

34. Together with T. Sällström and 0. Agren. Physiologische und pathologische Herzvolumenschwankungen.

Verh. dtsch. Ges. Kreislaufforsch. 1939, 369.

35. a) Discussion Acta med. scand. 1939, Suppl. CXХПI, 139.

35. b) Discussion Acta med. scand. 1939, Suppl. CXXIII, 168.

35. c) Discussion Acta med. scand. 1939, Suppl. CXXIII, 151.

d) Discussion Acta med. scand. 1939, Suppl. CXXIII, 317.

Together with H. von Euler and B. Högberg. Einfluß von Aneurin und Insulin auf den Zuckerund Brenztraubensäuregehalt des Blutes.

Klin. Wschr. 19, 433, 1940.

37. Discussion.

Nord. Med. 10, 770, 1941.

38. Together with G. Lüjestrand, Über die Wirkung von Digitalis, Cardiazol,

Coramin, Hexeton und Strychnin auf Kreislauf und Atmung.

Acta physiol. scand. I, 328, 1941.

Papers published by Gustav Nylin 213

39. a) William Withering - ett tvåhundraårsminne. Nord. Med. 9, 927, 1941.

39. b) William Withering - bicentuary tribute.

Amer. Heart J. 25, 285, 1943.

40. a) Om storleken och växlingarna av hjärtats restblodmängd.

Nord. Med. 10, 1139, 1941.

40. b) On the amount of, and changes in the residual blood of the heart.

Amer. Heart J. 25, 598, 1943.

41. Together with G. Líljestrand. Die Wirkung des Lacarnols und des Eutonons

auf das Herzminutenvolumen des gesunden Menschen.

Sehweiz. med. Wschr. 11, 121, 1941. Sondernummer für Herrn Prof. Dr. W. R. Hess.

42. Relation entre Thypertonie et le volume de sang résiduaire du cæur.

Acta radiol., Stockh. 22, 736, 1941.

43. a) Digitalis- och strophantusterapi.

Nord. Med. 13, 299, 1942.

43. b) Digitalis- und Stropantustherapie.

Cardiologia 7, 281, 1943.

44. Together with G. Malmström. Weitere Untersuchungen über die Bedeutung der verlängerten Kreislaufzeit für die Kardiologie.

Cardiologia 5, 333, 1942. 
45. a) Together with C. Crafoord. Elektrogram avledda simultant från vänster och höger ventrikel å människohjärtat in vivo. Nord. Med. 16, 3609, 1942.

45. b) Together with C. Crafoord. Das vom Menschenherzen in vivo simultan vom linken und rechten Ventrikel abgeleitete Elektrogramm. Cardiologia 6, 136, 1942.

46. Die Diagnostik der Concretio Pericardii.

Acta chir. scand. 76, 387, 1942.

47. Together with K. E. Grewin. Drei Brustabteilungen und ihr Wert im Vergleich

mit den Extremitätenableitungen und einigen anderen Brustableitungen.

Cardiologia 6, 169, 1942.

48. Coronarsjukdomens klinik.

Nord. Med. 18, 1045, 1943.

49. a) Together with Mígnon Malm. Über die Konzentration von mit radioaktivem Phosphor markierten Erythrocyten im Arterienblut nach der intra-venösen Injektion solcher Blutkörperchen. Cardiologia 7, 153, 1943.

49. b) Together with Mígnon Malm. Concentration of red blood corpuscules containing labelled phosphorous compounds in the arterial blood after intravenous injection. Amer. J. Med. Sci. 207, 743, 1944.

50. Together with G. Liljestrand. Borsäure und Standardstoffwechsel.

Acta physiol. scand. 5, 194, 1943.

51. a) Coronarinsufficiensens tidigdiagnostik.

Svenska Läkartidn. 41, 1134, 1944. 51. b) Die Frühdiagnose der Koronarinsuffizienz.

Cardiologia 8, 263, 1944.

$14^{*}$

214

Papers published by Gustav Nylin

52. a) Cirkulationsundersökning av Gunder Hägg och Arne Andersson. Svenska Läkartidn. 42, $361,1945$.

52. b) Investigations on the blood circulations of G. Hägg and A. Andersson. Cardiologia 9, 22, 1945.

53. a) Utspädningskurvan for aktiviteten i artärblod efter intravenös injektion av märkta blodkroppar. Nord. Med. 26, 1033, 1945.

53. b) The dilution curve of activity in arterial blood after the injection of labelled corpuscules.

Amer. Heart J. 30, 1, 1945.

54. a) Blodvolymsbestämningar med hjälp av radioaktiv fosfor i normala och cardiologiska fall.

Nord. Med. 26, 1095, 1945.

54. b) Blood volume determinations with radioactive phosphorus.

Brit. Heart J. 7, 81, 1945.

55. Studies on the circulation with the aid of blood corpuscules labelled with radioactive Phosphorus compounds.

Arkiv for Kemi, Mineralogi och Geologi, utgivet av K. Svenska Vetenskaps-akademien 1945, band 20 A, Nr. 17, s. 1.

56. Together with C. Crafoord. Congenital coarctation of the aorta and its surgical treatment.

J. thorac. Surg. 14, 347, 1945. 
57. a) Hjärtsjukdom och graviditet.

Nord. Med. 27, 1855, 1945.

57 . b) Heart disease and pregnancy.

Cardiologia 11, 151, 1946/47.

58. Discussion. Radioaktiva isotopers användning vid bloddepåundersökningar. Nord. Med. 29, 326, 1946.

59. Together with G. Biörck. Scarifikation - en användbar terapiform.

Nord. Med. 29, 487, 1946.

60. Hjärtinfarktens diagnos och behandling.

Svenska Läkartidn. 43, 2713, 1946.

61. Together with J. Naeslund. Investigations on the permeability of the placenta with the aid of red blood corpuscules tagged with radioactive Phosphorus.

Acta med. scand. 1946, Suppl. CLXX.

62. Together with G. Biörck, Ada Elmqvíst and H. Rydin. Orienterande jäm-

förande djurexperimentella och kliniska studier over folium digitalis pur-

pureae och lanatae.

Nord. Med. 30, 1130, 1946.

63. a) Together with B. Gernandt. Sambandet mellan cirkulationstid och hjärtats restblodmängd.

Nord. Med. 30, 1386, 1946.

63. b) Together with B. Gernandt. The relation between circulation time and the amount of the residual blood of the heart. Amer. Heart J. 32, 411, 1946.

64. Together with B. Ejrup, H. Gladnikoff and C. Crafoord. Istmusstenosens

klinik, diagnostik och behandling.

Nord. Med. 32, 2517, 1946.

Papers published by Gustav Nylin 215

65. a) Adrenalins inverkan på den cirkulerande blodkroppsmängden. Nord. Med. 33, 265, 1947.

65. b) The effet of adrenalin injected intravenously on the volume of circulating

erythrocytes.

Acta cardiol. 3i4, 225, 1946.

66. a) Together with R. Pannier. Ortostatismens och shockens inflytande på

cirkulationshastigheten, bestämd med hjäl·p av radioaktivt fosfor. Nord. Med. 34, 1065, 1947.

66. b) Together with R. Pannier. L'inftuence de $\Gamma$ orthostatisme et du shock sur

la vitesse circulatoire déterminée à $\Gamma$ aide du phosphore radioactif. Arch. int. Pharmacodyn. 73, 401, 1947.

67. a) Cirkulerande blodmängden i vissa enskilda organ.

Nord. med. 33, 263, 1947.

67. b) The circulatory blood volume of some organs.

Amer. Heart J. 34, 174, 1947.

68. a) Undersökning over den cirkulerande blodmängden efter kroppsansträngning hos människa.

Svenska Läkartidn. 43, 3137, 1946.

68. b) The effect of heavy muscular work on the volume of circulating red corpuscles in man.

Amer. J. Physiol. 149, 180, 1947.

69. a) Extrem minskning av hjärtats restblodmängd under kortvarig poliklinisk 
intravenös cedilanidbehandling. Nord. Med. 33, 65, 1947.

69. b) Ausgesprochene Abnahme der Restblutmenge des Herzens in einem Fall

von Herzinsuffizienz nach dreiwöchiger intravenöser Cedilanidtherapie. Cardiologia 21, 1, 1946/47.

70. Together with G. Biörck. Phonocardiograms of auricular murmurs from a case with mitral stenosis and heart block.

Brit. Heart J. 9, 16, 1947.

71. Translated from American Heart Journal 23,161,1942 with a personal addition:

Paul D. White: Cardiologi såsom specialitet.

Svenska Läkartidn. 44, 1567, 1947.

72. Together with G. Biörck. Circulatory corpuscle and blood volume in a case of patent ductus arteriosus before and after ligation.

Acta med. scand. 127, 434, 1947.

73. Cardiac function from theoretical and practical points of view.

Arch. Inst. Cardiol. Mex. 17, 243, 1947.

74. Together with S. Hedlund. Weight of the red blood corpuscles in heart failure determined with labelled erythrocytes during and after decompensation.

Amer. Heart J. 33, 770, 1947.

75. Together with M. Levander. Studies on the circulation with the aid of tagged erythrocytes in a case of orthostatic hypotension (asympathicotonic hypo

tension).

Ann. intern. Med. 28, 723, 1948.

76. Together with S. Hedlund. Variations in the quantity of red blood corpuscles

in cases of heart failure.

Acta med. scand., 1948, Suppl. CCVI.

216

Papers published by Gustav Nylin

77. Radioactively labelled erythrocytes employed in studies of the velocity of the

blood flow and of the circulatory corpuscle volume.

Memorias del segundo congreso interamericano de cardiologia. Mexico City 3, 1378, 1946.

78. a) Den kroniska hjärtinsufficiensens behandling.

Nord. Med. 37, 570, 1948.

b) Treatment of chronic heart failure. Arch. Inst. Card. Mex. 19, 280, 1949.

Together with S. Hedlund. Further studies of the circulation with radioactive erythrocytes.

Amer. Heart J. 37, 543, 1949.

80. Together with Hjördís Celander. Determinations of the blood volume in the heart and lungs and the cardiac output through the injection of radiophos-

phorus.

Circulation J, 76, 1950.

81. Greeting from Europe. - Read at Inaugural Session of the Interamerican

Congress of Cardiology in Chicago, June 1948.

Amer. Heart J. 37, 484, 1949.

Cardiovascular Clinic. II. Medical Department, Södersjukhuset, Stockholm, 1949.

a) Aktuella synpunkter och problem inom vår tids cardiologi. Högtidsföredrag vid Svensk förenings for cardiologi årsmöte den 24 September 1949.

83. b) Topical aspects and problems of present day cardiology. 
Cardiologia 17, 50, 1950.

84. Noradrenalins roll i dagens hypertoniforskning.

Nord. Med. 41, 1110, 1949.

85. Ned atommärkta blodkroppar genom hjärta och andra organ.

Atomåldern 1949.

86. Together with S. Hedlund. Die Anwendung der Isotopen in der Cardiologie. Berl. med. Z. J, 217, 1950.

87. Together with A. Kappert, G. C. Sutton, A. Reale and C.-H. Skoglund. The clinical response of human beings to 1-noradrenaline and its clinical applica

bility.

Acta cardiol., Brux. 2, 121, 1950.

88. Together with K. E. Grewín and B. Ejrup. Über Arbeitsmethoden und Ergebnisse der Herzklinik im Stockholmer Südkrankenhaus.

Berl. med. Z. J, 224, 1950.

89. Together with G. C. Sutton and J. Kamell. Studies on the rapidity of complete blood circulation in man.

Amer. Heart J. 39, 741, 1950.

90. Nekrolog over George Richards Minot.

Nord. Med. 43, 924, 1950.

91. Together with G. C. Sutton, A. Kappert, A. Reale and C.-H. Skoglund. Studies on 1-nor-epinephrine: relation of dosage to pressor and bradycardia effect.

J. Lab. clin. Med. 36, 460, 1950.

92. Together with G. C. Sutton, A. Kappert, A. Reale and C.-H. Skoglund. The effect of 1-nor-epinephrine upon the corpuscular volume and hematocrit.

Amer. Heart J. 40, 396, 1950.

Papers published by Gustav Nylin

217

93. Allocution du Professeur Nylin.

Arch. Mai. Cæur, 10, 885, 1950.

94. Together with V. de Fazio and F. Marsíco. The hypoxemia test: An analysis of 1130 tests.

Cardiologia 17, 191, 1950.

95. Erythrocytes labelled with P32 in studies of the circulation.

Acta med. scand. 1951, Suppl. CCLIX.

96. Studies of the changes in the amount of the residual blood of the heart in man.

Cardiologia 17, 251, 1950.

97. Vegolysinbehandling vid essentiell hypertension.

Svenska Läkartidn. 48, 1007, 1951.

98. Together with G. Wade. The loss of activity from blood cells and plasma which have been labelled with radioactive phosphorus (P32).

Arkiv for Kemi, Kungl. Sv. Vetenskapsakademien 3, 413, 1951.

99. Together with G. de Hevesy. Application of K42 labelled red corpuscles in blood volume measurements.

Acta physiol. scand. 24, 285, 1951.

100. Isolated mitral stenosis. 
Acta med. scand. 1952, Suppl. CCLXVI. (Volume dedicated to Prof. Erik Warburg, Copenhagen.)

101. Together with J. C. Scott-Baker and J. Karnell. Studies on the polycythemic reaction in cyanotic congenital heart disease by means of erythrocytes labelled with P32.

C. R. du Congrès Mondial de Cardiologie, Paris 1950.

102. Aktuellt om hjärtsjukdomar. Ny kunskap.

Natur och Kultur 1952.

103. Together with A. Kappert, C.-H. Skoglund and A. Bergholtz. The effects of Hydergine (CCK) on reflex vasoconstriction and reflex pressure stimulation.

Acta med. scand. 141, 440, 1952.

Together with G. de Hevesy. Application of "Thorium B" labelled erythrocytes in studies of the circulation. In press.

Oxygen debt in valvular stenosis. In press. 